\title{
PELINDUNGAN HAK CIPTA PADA PENGGUNAAN GAMBAR DI INTERNET YANG DIJADIKAN DESAIN PADA FITUR FILTER CERITA (STORIES) APLIKASI INSTAGRAM SECARA TANPA HAK UNTUK TUJUAN KOMERSIL
}

\author{
Kartika Andini ${ }^{1}$, Rika Ratna Permata ${ }^{2}$, Miranda Risang Ayu ${ }^{3}$ \\ ${ }^{1}$ Fakultas Hukum, Universitas Padjadjaran, Bandung, Indonesia kartika17002@mail.unpad.ac.id \\ ${ }^{2}$ Fakultas Hukum, Universitas Padjadjaran, Bandung, Indonesia \\ ${ }^{3}$ Fakultas Hukum, Universitas Padjadjaran, Bandung, Indonesia
}

\section{ABSTRACT}

Image on the internet is an object of copyright protection and is a work that arises from someone's idea. This study aims to examine the protection of image on the internet that is used illegally for commercial purposes by the designer of a filter of Instagram Stories. To solve the problem, this research uses a normative juridical method, especially the descriptive analytical method, by analyzing the Copyright Law Number 28 of 2014 and the Information, Electronic Transactions Law Number 11 of 2008. The results of this research show that image on the internet is protected by copyright. In Indonesia, the protection of image on the internet is regulated by the Copyright Law Number 28 of 2014 and the Information, Electronic Transactions Law Number 11 of 2008. Copyright protection on the over-the-top media like Instagram is also regulated by the Government Regulation Number 71 of 2019 about Implementation System of Electronic Transactions. Based on the laws and regulation, protection is given to the author of image on the internet, including the designer of the filter of Instagram Stories, so the work cannot be used illegally in a manner that harmful to the author.

\section{ARTICLE INFO}

\section{Keywords:}

Copyrights; digital media;

filter of Instagram Stories;

image on the internet

\section{Cite this paper:}

Kartika Andini, R. R.

(2021). Pelindungan Hak

Cipta Pada Penggunaan

Gambar Di Internet Yang

Dijadikan Desain Pada Fitur

Filter Cerita (Stories)

Aplikasi Instagram Secara

Tanpa Hak Untuk Tujuan

Komersil. Widya Yuridika:

Jurnal Hukum, 4(2).

Scope Article

Human Rights

\section{PENDAHULUAN}

Kemajuan teknologi menimbulkan suatu keadaan baru dan perubahan situasi di kehidupan manusia. Kehadiran teknologi informasi dan komunikasi telah menyentuh berbagai aspek kehidupan masyarakat diantaranya sosial budaya, ekonomi, agama, dan kerangka hukum. Salah satu bentuk pemanfaatan teknologi informasi dan komunikasi ialah hadirnya teknologi internet. Perkembangan teknologi internet telah menciptakan suatu ruang baru yakni dunia maya atau ranah siber. Menurut Ahmad M Ramli adanya perubahan dunia menuju era digital dapat merubah dan meningkatkan kinerja produktivitas karena memungkinkan untuk melakukan seluruh aktivitas tanpa melalui hambatan. ${ }^{1}$ Informasi

\footnotetext{
${ }^{1}$ Tasya Safiranita Ramli, Ahmad M Ramli, Rika Ratna Permata. Aspek Hukum Atas Konten Hak Cipta Dikaitkan dengan Undang-Undang Nomor 19 Tahun 2016 Tentang Informasi dan Transaksi Elektronik, Jurnal Legislasi Indonesia Vol 17 No 1, 2020, HIm 65.
} 
dapat diperoleh, dipertukarkan, diakses, didistribusikan, dan ditransmisikan dengan mudah pada era digital dengan kehadiran teknologi internet. ${ }^{2}$

Kehadiran era digital memberikan perubahan pada berbagai aspek salah satunya dalam pengembangan karya cipta. Berbicara mengenai suatu karya cipta erat kaitannnya dengan pembahasan Kekayaan Intelektual dalam ruang lingkup Hak Cipta. Kekayaan intelektual ialah hasil dari pemikiran dan kecerdasan seseoraang yang berbentuk penemuan, desain, seni, karya tulis, atau penerapan praktis suatu ide. ${ }^{3}$ Mennurut McKeough and Stewart KI adalah hak yang memberikan perlindungan hukum pada hasil kreativitas manusia yang memiliki nilai ekonomi. ${ }^{4}$ Sedangkan Hak Cipta merupakan hak eksklusif pencipta yang timbul secara otomatis berdasarkan prinsip deklaratif setelah suatu ciptaan diwujudkan dalam bentuk nyata tanpa mengurangi pembatasan sesuai dengan ketentuan peraturan perundang-undangan. 5

Dewasa ini, banyak pencipta yang memanfaatkan perkembangan teknologi untuk kebutuhan penciptaan dan publikasi karya cipta miliknya. Dalam proses penciptaan pencipta menggunakan aplikasi atau program tertentu untuk membuat dan mengedit gambar dalam bentuk format digital. Selain itu, pencipta memanfaatkan media sosial, aplikasi serta situs-situs penyedia gambar untuk mempublikasikan karyanya. Namun, di samping kemudahannya karya cipta yang tersebar di internet juga berisiko atas pelanggaran hak cipta.

Pada pertengahan tahun 2020, muncul suatu tren pada media sosial Instagram yakni pembuatan desain filter cerita Instagram (Instagram stories) oleh pengguna Instagram. Tren ini tidak hanya dijadikan sebagai ajang untuk meningkatkan kreativitas namun dijadikan sebagai ladang bisnis baru oleh berbagai pihak. Melihat besarnya keuntungan yang didapatkan dari penjualan desain filter cerita Instagram (Instagram Stories) membuat beberapa pihak membuat filter cerita Instagram (Instagram stories) dengan pilihan desain yang variatif.

Dalam penulusuran yang dilakukan terdapat beberapa penjual desain filter yang tidak menciptakan karyanya secara orisinil. Hal ini terlihat pada unsur-unsur gambar yang digunakan dalam desain filter miliknya. Terdapat beberapa penjual yang mengambil gambar-gambar yang tersebar di internet tanpa memperhatikan ketentuan penggunaan hak cipta. Adapun gambar yang digunakan secara tanpa hak ialah gambar yang berlisensi nonkomersil ataupun gambar-gambar karakter animasi yang telah memiliki hak cipta atasnya. Digitalisasi konten seperti ini memudahkan terjadinya manipulasi karya oleh pihak yang tidak bertanggung jawab. ${ }^{6}$ Pencurian hingga penjualan karya gambar digital tanpa izin pencipta merupakan akibat dari minimnya pengetahuan masyarakat tentang hak cipta. ${ }^{7}$

Permasalahan di atas dapat merugikan hak eksklusif pencipta gambar di internet. UU Nomor 28 Tahun 2014 tentang Hak Cipta (Selanjutnya disebut dengan UU Hak Cipta) sendiri telah menjamin bahwa pencipta mendapatkan hak esklusif atas ciptaanya yakni hak moral dan hak ekonomi. Salah satu hak moral yang didapatkan ialah pencantuman nama pencipta

\footnotetext{
2 Fitri Murfianti. "Hak Cipta dan Karya Seni di Era Digital". Jurnal Asintya: Jurnal Penelitian Seni Budaya. Vol 12 No 1 Juni 2020. HIm 44

${ }_{3}$ Made Angga Adi Suryawan, \& Made Gde Subha Karma Resen. “Pelaksanaan Penarikan Royalti Oleh Yayasan Karya Cipta Indonesia Wilayah Bali Pada Restoran Di Kabupaten Gianyar Atas Penggunaan Karya Cipta Lagu Dan Musik." Kertha Semaya: Journal Ilmu Hukum 4.3 (2018): 1-13, hlm. 5

${ }^{4}$ Sudjana. "Pembatasan Perlindungan Kekayaan Intelektual (Hak Cipta) dalam Perspektif Hak Asasi Manusia". Jurnal HAM. Vol 10, No 1, Juli 2019. HIm 72

${ }^{5}$ Lihat Pasal 1 Angka 1 Undang-Undang Nomor 28 Tahun 2014 tentang Hak Cipta

${ }^{6}$ Fitri. Op Cit., 44

${ }^{7}$ I Gede Ari Krisnanta Permana, Ratna Artha Windari, \& Dewa Gede Sudika Mangku. “Implementasi UndangUndang Nomor. 28 tahun 2014 tentang Hak Cipta Terhadap Perlindungan Karya Cipta Program Komputer (Software) Di Pertokoan Rimo Denpasar." Jurnal Komunitas Yustisia 1.1 (2020): 55-65, hlm. 58.
} 
pada ciptaannya sedangkan salah satu hak ekonomi yang didapatkan oleh pencipta adalah hak distribusi. Pendistribusian merupakan penjualan, pengedaran, dan/atau penyebaran ciptaan dan/atau produk hak terkait. ${ }^{8}$ UU Hak Cipta menegaskan bahwa bagi pihak lain yang melanggar hak eksklusif pencipta dapat ditindak secara hukum dengan memperhatikan ketentuan peraturan perundang-undangan yang berlaku. Adapun dalam kaitannya pada Hak Cipta di ranah dunia siber maka selain menggunakan UU Hak Cipta perlu dilihat pula penegakan hukum pada Undang-Undang Nomor 19 Tahun 2016 tentang Informasi dan Transaksi Elektronik (Selanjutnya disebut UU ITE) serta Peraturan Pemerintah Nomor 71 Tahun 2019 tentang Penyelenggaran Sistem dan Transaksi Elektronik (Selanjutnya disebut PP PTSE)

Berdasarkan penjabaran di atas, penulis tertarik untuk meneliti mengenai permasalahan penggunaan gambar di internet secara tanpa hak oleh pencipta desain filter cerita Instagram (Instagram stories) dalam sebuah penelitian ilmiah yang berjudul "PelindunganHak cipta Pada Penggunaan Gambar di Internet yang Dijadikan Desain Pada Fitur Filter Cerita (stories) Aplikasi Instagram Secara Tanpa Hak Untuk Tujuan Komersil". Pada penelitian ini terdapat dua fokus pembahasan yakni mengenai pengaturan UU Hak Cipta pada penggunaan gambar di internet yang digunakan tanpa hak untuk tujuan komersil pada desain filter cerita (stories) aplikasi Instagram dan tindakan hukum yang diberlakukan atas hal tersebut berdasarkan UU Hak Cipta dan UU ITE. Berdasarkan permasalahan tersebut, maka tujuan dari penelitian ini adalah untuk menambah pengetahun terhadap permasallahan yang berkaitan dengan Hak Kekayaan Intelektual khususnya hak cipta di di media digital serta untuk menjawab fokus permasalahan yang sudah dirumuskan di dalam penelitian ini

\section{METODE}

Metode penelitian yang digunakan dalam penulisan ini ialah metode yuridis normative. Dilakukan dengan cara menganalisis data sekunder berdasarkan norma-norma, kaidah, doktrin-doktrin hukum serta asas yang dikenal di dalam bidang ilmu hukum. Adapun penelitian ini bersifat deskriptif analitis yaitu suatu penelitian yang menjelaskan dan menganalisis permasalahan dengan memperhatikan peraturan yang berlaku melalui pendekatan perundang-undangan. ${ }^{9}$

\section{HASIL DAN PEMBAHASAN}

\section{Pelindungan Hukum Pencipta Gambar di Internet Terhadap Penggunaan Ciptaan yang digunakan secara tanpa hak pada Desain Filter Cerita (Stories) Instagram}

Hak Cipta merupakan hak eksklusif yang diberikan terhadap objek pelindungan karya intelektual yang diwujudkan dalam bentuk nyata. ${ }^{10}$ Di Indonesia kepastian hukum atas pelindungan Hak Cipta dibuktikan dari adanya UU Nomor 28 Tahun 2014 tentang Hak Cipta. Sedangkan mengenai perlindungan ciptaan di internet di atur dalam Pasal 25 UU Nomor 11 Tahun 2008 juncto Undang-Undang Nomor 19 Tahun 2016 tentang Informasi dan Transaksi Elektronik. Pasal tersebut menjelaskan bahwa informasi elektronik dan/atau dokumen elektronik yang disusun menjadi karya intelektual, situs internet dan karya intelektual yang ada di dalamnya dilindungi sebagai Hak Kekayaan Intelektual berdasarkan ketentuan Peraturan Perundang-undangan. ${ }^{11}$

\footnotetext{
8 UU No. 28 Tahun 2014 Tentang Hak Cipta

9 Junimart Girsang, et al. "Pertanggungjawaban Hukum Perusahaan Asuransi Terhadap Penolakan Klaim Atas Kehilangan Kendaraan Bermotor." Justitia: Jurnal Ilmu Hukum dan Humaniora 7.4 (2020): 819-829, hlm. 825. ${ }^{10}$ Abel Nicholas L. Tobing., Rika Ratna Permata., dan Tasya Safiranita Ramli., Tindakan Hukum atas Pelanggaran Hak Cipta pada Digitalisasi Ciptaan Melaui Media Over The Top. Jurnal Sains Sosio Humaniora, Volume 5 Nomor 1. Juni 2021. HIm 564.

${ }^{11}$ Undang-Undang Nomor 11 Tahun 2008 juncto Undang-undang Nomor 19 Tahun 2016 Tentang Informasi dan Transaksi Elektronik
} 
Kemudahan dalam penggunaan ciptaan di medium digital telah memberikan kebebasan pada pengguna dalam memanfaatkan ciptaan tersebut. Disamping itu, pemanfaatan ciptaan di internet juga berisiko atas terjadinya pelanggaran hak cipta. ${ }^{12}$ Seperti adanya pihak yang tidak bertanggung jawab yang mengeksploitasi dan mengkomersialisasikan suatu konten hak cipta yang terdapat di internet. Perbuatan tersebut tentu dapat merugikan pencipta yang telah dengan mengorbankan usaha, biaya serta waktunya. Selain itu perubahan atas perwujudan suatu karya dari medium konvensional menjadi medium digital tidak menghilangkan hak serta pelindungan atas pencipta dan ciptaannya.

Kasus penggunaan gambar di internet secara tanpa hak dalam pembuatan desain filter cerita Instagram (Instagram stories) menjadi perhatian atas pelindungan bagi pencipta gambar di internet. Dalam Pasal 1 Angka 2 dijelaskan yang dimaksud dengan pencipta ialah seseorang atau beberapa orang yang secara sendiri-sendiri atau bersama-sama menghasilkan suatu ciptaan yang bersifat khas dan pribadi. ${ }^{13}$ Berdasarkan pasal tersebut, tidak semua orang yang menciptkan suatu karya mendapatkan pelindungan ciptaan. Perlu adanya pembuktian bahwa ciptaan yang dihasilkan bukanlah hasil duplikasi dan/atau penggunaan illegal atas ciptaan milik pihak lain.

Bentuk pelindungan yang diberikan oleh seorang pencipta diantaranya pemberian hak eksklusif yakni hak moral dan hak ekonomi. Hak moral dalam terminologi Bern Convention menggunakan istilah moral rights, yakni hak yang dilekatkan pada diri pencipta. ${ }^{14}$ Salah satu hak moral dari pencipta ialah dengan dicantumkan/tidak dicantumkan namanya dalam ciptaan. Sedangkan hak ekonomi berdasarkan Pasal 8 UU Hak Cipta merupakan hak yang dimiliki pencipta untuk mendapatkan manfaat ekonomi atas ciptaannya. Salah satu hak ekonomi pencipta ialah hak distribusi berdasarkan Pasal 9 UU Hak Cipta. Hak Pendistribusian ialah penjualan, pengedaran, dan/atau penyebaran ciptaan dan/atau produk hak terkait. ${ }^{15}$

Selain penjelasan mengenai subyek pelindungan Hak Cipta dan hak yang melekat atasnya UU Hak Cipta juga mengatur mengenai obyek pelindungan. Pasal 1 angka 3 UU Hak Cipta menjelaskan bahwa objek pelindungan hak cipta ialah karya cipta pada aspek ilmu pengetahuan, sastra, maupun seni yang telah diwujudkan dalam suatu bentuk nyata. Gambar di Internet termasuk ke dalam objek pelindungan hak cipta karena berdasarkan pasal 40 ayat (1) gambar merupakan bentuk karya seni rupa. Dalam perspektif hukum siber ciptaanciptaan yang diunggah di media internet termasuk obyek yang dilindungi. ${ }^{16}$ Mengacu pada Pasal 1 UU ITE dijelaskan bahwa gambar di internet dapat dikategorikan sebagai suatu informasi elektronik yang dapat dipahami oleh orang yang mampu memahaminya.

Gambar di internet biasanya dapat ditemukan di berbagai situs dan aplikasi khusus penyedia gambar seperti Google, Pinterest, Shutterstock, Picsart dan lainnya. Dalam aplikasi dan situs penyedia gambar terdapat berbagai gambar yang dapat dimanfaatkan oleh penggunanya. Sebagai bentuk pelindungan ciptaan penyedia situs memberlakukan suatu ketentuan khusus pada gambar yang tersedia di situsnya. Misalnya dengan memberlakukan suatu lisensi yang disesuaikan dengan syarat dan ketentuan pada situs dan aplikasi tersebut. Bentuk pelindungannya ialah pemberian keterangan tambahan mengenai batasan penggunaan pada setiap gambar yang ada dalam situs atau aplikasi tersebut.

\footnotetext{
12 Putri Yan Dwi Akasih. Perlindungan Hak Cipta di Internet Melalui Creative Commons. Business Law Review, Volume 2. HIm 13

${ }^{13}$ Undang-Undang Nomor 28 Tahun 2014 tentang Hak Cipta

${ }^{14}$ OK Saidin, Aspek Hukum Hak Kekayaan Intelektual (Intellectual Property Rights), Raja Grafindo Persada, Jakarta, 2015, hlm 250.

${ }^{15}$ Pasal 1 Angka 17 UU Nomor 28 Tahun 2014 tentang Hak Cipta

${ }^{16}$ Sudjana. Sistem Perlindungan Atas Ciptaan Berdasarkan Undang-Undang Nomor 28 Tahun 2014 Tentang Hak Cipta dalam Perspektif Cyber law. Jurnal Ilmu Hukum Universitas Parahyangan. Vol 2 No 2 Desember 2016. HIm 260
} 
Aturan yang terdapat dalam UU Hak Cipta telah mengatur mengenai pelindungan atas digitalisasi ciptaan. ${ }^{17}$ Adanya ketentuan yang berlaku dalam suatu karya cipta di internet bukanlah sebagai penghambat para pengguna internet dalam pemanfaatan atas karya tersebut. Dalam Pasal 43 UU Hak Cipta dijelaskan mengenai pembatasan hak cipta tentang perbuatan mana yang tidak dianggap sebagai pelanggaran hak cipta. Salah satunya ialah pembuatan dan penyebarluasan konten Hak Cipta melalui media teknologi informasi dan komunikasi yang bersifat tidak komersial dan/atau menguntungkan Pencipta atau pihak terkait, atau Pencipta tersebut menyatakan tidak keberatan atas pembuatan dan penyebarluasan tersebut. Oleh karena itu, batasan pengguna tidak melakukan pelanggaran hak cipta apabila suatu karya tidak digunakan untuk kepentingan komersil dan disertai dengan pencantuman nama pencipta pada konten tersebut. 18

Penggunaan gambar di internet secara tanpa hak dalam unsur desain filter cerita Instagram (Instagram stories) menyebabkan pencipta desain tidak mendapatkan pelindungan hak cipta. Hal ini dikarenakan pencipta yang mendapatkan pelindungan adalah yang menghasilkan ciptaan yang sifatnya khas dan orisinil. Adapun dalam kasus tersebut pencipta desain filter cerita Instagram (Instagram stories) selain mengambil secara tanpa hak karya milik orang lain juga mengomersialisasikan ciptaan tersebut. Perbuatan ini jelas telah melanggar hak eksklusif yang dimiliki oleh pencipta yakni hak ekonomi dalam hal pendistribusian. Pencipta desain filter tidak berhak atas penjualan tersebut. Terlebih lagi apabila gambar yang digunakan dalam desainnya merupakan gambar yang berlisensi nonkomersil. Berdasarkan pasal 43 perbuatan yang dilakukan oleh pencipta desain bukan termasuk pembatasan hak cipta dan merupakan suatu pelanggaran hak cipta.

Jika ketentuan lisensi menyatakan bahwa ciptaan dilarang digunakan untuk kepentingan komersil maka penerima lisensi wajib meminta izin dan/atau membayar sejumlah royalti kepada pemberi lisensi. ${ }^{19}$ Namun, apabila ketentuan lisensi menyatakan bahwa ciptaan dapat digunakan untuk kepentingan komersil maka penerima lisensi secara langsung diizinkan untuk menggunakan ciptaan dalam kepentingan komersil. ${ }^{20}$

Penggunaan medium digital dalam penyebaran dan pembuatan karya cipta memang memberikan kemudahan dan keuntungan baik bagi pencipta maupun pengguna internet. Para pengguna banyak memanfaatkan medium digital karena efisien dan praktis dibanding dengan produk fisik yang membutuhkan perlakuan khusus seperti penyimpanan dan pengiriman yang harus dilakukan secara konvensional. ${ }^{21}$ Namun, kemudahan ini juga dapat dimanfaatkan oleh para pihak yang tidak bertanggung jawab untuk mengkopi dan/atau menjiplak suatu ciptaan untuk kepentingan pribadi. Misalnya, Pencipta desain filter cerita Instagram (Instagram stories) yang tidak memperhatikan ketentuan Hak Cipta pada gambar yang digunakan dalam unsur desainnya. Perbuatan para pelaku jelas melanggar fatsun hukum yang menentukan agar setiap orang dapat mematuhi, menghormati, dan menghargai hak-hak orang lain dalam hubungan keperdataan termasuk penemuan baru sebagai ciptaan orang lain yang diakui sebagai hak milik oleh ketentuan hukum. ${ }^{22}$

\footnotetext{
${ }^{17}$ Tasya Safira Ramli, Ahmad M. Ramli, Rika Ratna Permata, Danrivanto Budhijanto. Commercialization Of Copyright Content Through Digital Platforms In Indonesia. Progresive Law Review. Vol 1 No 1. November 2019. $\mathrm{HIm} 5$

${ }^{22}$ Akhmad Munawar \& Taufik effendy, Upaya Penegakan Hukum Pelanggaran Hak Cipta Menurut Undang-Undang Nomor 28 Tahun 2014 Tentang Hak Cipta, Jurnal Al'adl, Volume VIII Nomor 2 Mei-Agustus, 2016 hlm 135
} 


\section{Tindakan Hukum yang dilakukan oleh Pencipta Gambar terkait Komersialisasi Ciptaan pada Desain Filter Cerita Instagram (Instagram stories)}

Permasalahan mengenai penggunaan gambar di internet pada desain filter cerita Instagram (Instagram stories) yang digunakan secara tanpa hak untuk tujuan komersil merupakan suatu perbuatan yang dikategorikan pelanggaran Hak Cipta. Pelanggaran ini merupakan bentuk pelanggaran atas hak eksklusif pencipta yang dilakukan di media internet. Pelanggaran ini menyebabkan adanya kerugian yang dirasakan oleh salah satu pihak yakni pencipta gambar di internet yang ciptaannya digunakan secara tanpa hak dan dikomersialisasikan oleh pencipta desain filter cerita Instagram (Instagram stories). Oleh karena itu, pencipta dapat melakukan tindakan hukum atas pelanggaran Hak Cipta tersebut.

Pihak yang dirugikan dapat membuktikan adanya pelanggaran atas ciptaanya berdasarkan Pasal 5 Undang-Undang Nomor 11 Tahun 2008 juncto Undang-undang Nomor 19 Tahun 2016 Tentang Informasi dan Transaksi Elektronik (Selanjutnya disebut dengan UU ITE) yang berbunyi :

1. Informasi elektronik dan/atau dokumen elektronik dan/atau hasil cetaknya merupakan alat bukti hukum yang sah

2. Informasi elektronik dan/atau dokumen elektronik dan/atau hasil cetaknya sebagaimana dimaksudkan pada ayat (1) merupakan perluasan dari alat bukti yang sah sesuai dengan hukum acara yang berlaku di Indonesia

3. Informasi elektronik dan/atau dokumen elektronik dinyatakan sah apabila menggunakan sistem elektronik sesuai dengan ketentuan yang diatur dalam undang-undang ini.

4. Ketententuan mengenai informasi elektronik dan/atau dokumen elektronik sebagaimana dimaksud pada ayat (1) tidak berlaku untuk:

a. Surat yang menurut Undang-undang harus dibuat dalam bentuk tertulis, dan

b. Surat berserta dokumennya yang menurut Undang-undang harus dibuat dalam bentuk akta notaris atau akta yang dibuat oleh pejabat pembuat akta

Setelah adanya pembuktian atas pelanggaran tersebut pencipta dapat melakukan dua tindakan hukum yaitu tindakan hukum preventif dan tindakan hukum represif. ${ }^{23}$ Tindakan hukum preventif merupakan langkah untuk mengurangi dan/atau mencegah terjadinya kegiatan pelanggaran terkait hak moral dan hak ekonomi sedangkan tindakan hukum represif yakni tindakan yang dilakukan setelah terjadinya pelanggaran hukum. Tindakan hukum represif merupakan langkah akhir untuk menangani permasalahan pelanggaran Hak Cipta, dapat dilakukan dengan cara damai atau berupa sanksi denda dan pidana penjara. ${ }^{24}$ Tindakan hukum represif dibedakan atas dua yakni melalui jalur non-pengadilan dan jalur pengadilan.

1. Jalur Non-Pengadilan

Pengaturan mengenai tindakan hukum represif melalui jalur non-pengadilan sendiri diatur dalam Pasal 95 ayat (4) UU Hak Cipta yang menjelaskan bahwa:

"Selain pelanggaran Hak Cipta dan/atau Hak terkait dalam bentuk Pembajakan, sepanjang para pihak yang bersengketa diketahui keberadaannya dan/atau berada di wilayah Negara Kesatuan Republik Indonesia harus menempuh terlebih dahulu penyelesaian sengketa melalui mediasi sebelum melakukan tuntuntan pidana."

\footnotetext{
${ }^{23}$ Anak Agung Sinta Paramisuari, \& Sagung Putri ME Purwani. Perlindungan Hukum Ekspresi Budaya Tradisional Dalam Bingkai Rezim Hak Cipta. Kertha Semaya: Journal Ilmu Hukum 7.1 (2019): 1-16 hlm. 9

${ }^{24}$ Pani sopian, Ranti Fauza Mayana, \& Tasya Safiranita. Perlindungan Hak Cipta Terkait Gambar Karakter Disney yang di Transmisi Secara Ilegal melalui Media Elektronik, Jurnal Kertha Semaya, Vol 9 No. 6 Tahun 2021, hlm 1059
} 
Berdasarkan penjelasan pasal di atas para pihak yang bersengkata dianjurkan untuk terlebih dahulu menyelesaikan sengketa menggunakan jalur di luar persidangan. Adapun langkah penyelesaian sengketa diluar pengadilan dapat dibedakan menjadi beberapa cara yaitu Konsultasi, Negosiasi, Mediasi, dan Konsiliasi. Selain cara-cara tersebut dalam sengketa Hak Cipta juga terdapat penyelesaian melalui jalur arbitrase. Keunggulan jalur arbitrase sendiri ialah terjaminnya kerahasiaan karena dilakukan secara tertutup sehingga putusannya pun tidak akan dipublikasikan kepada masyarakat umum.

2. Jalur Pengadilan

Penyelesaian sengketa melalui jalur pengadilan dibedakan menjadi dua yakni melalui gugatan perdata dan tuntutan pidana. Dalam kasus komersialisasi gambar di internet secara tanpa hak oleh pencipta desain filter cerita Instagram (Instagram stories) maka berdasarkan UU Hak Cipta dalam Pasal 96,97, dan 99 pengadilan yang berwenang untuk menangani kasus ini ialah Pengadilan Niaga. Pencipta dapat mengajukan gugatan dengan dasar gugatan mengalami kerugian hak ekomoni. Kemudian mengenai tuntutan pidana pihak yang melakukan pelanggaran akan dikenakan sanksi berupa pidana penjara dan/atau pidana denda. Mengenai kasus di atas dapat mengacu pada ketentuan pasal 113 ayat (3) yang menjelaskan mengenai pelanggaran hak ekonomi yakni hak pendistribusian dapat dipidana penjara paling lama (4) tahun dan/atau pidana denda paling banyak Rp1.000.000.000,00 (satu miliar rupiah).

Kasus komersialisasi gambar di internet secara tanpa hak oleh pencipta desain filter cerita Instagram (Instagram stories) merupakan pelanggaran yang terjadi di media Over The Top. Layanan Over The Top ialah layanan yang menggunakan internet untuk memberikan manfaat bagi pengguna terhadap konten-konten yang terdapat di dalamnya yakni informasi berupa suara atau pesan suara, video, dan pengiriman pesan. ${ }^{25}$ Dalam pelanggaran yang terjadi di media Over the Top seperti Instagram, pihak yang dirugikan dapat mengajukan laporan kepada Direktorat Jenderal Kekayaan Intelektual untuk selanjutnya dilakukan pemrosesan kasus. Instagram sebagai suatu layanan media Over The Top dalam penyelanggaraan sistem elektroniknya harus berdasarkan ketentuan dalam PP PTSE. Berdasarkan Pasal 5 PP PTSE Penyelenggara Sistem Elektronik wajib memastikan sistem elektroniknya tidak memuat informasi elektronik dan tidak memfasilitasi penyebarluasan informasi elektronik yang dilarang sesuai dengan ketentuan perundang-undangan.

Aplikasi Instagram sendiri memiliki beberapa ketentuan mengenai pelindungan Hak Cipta atas konten yang tersedia pada aplikasinya. Instagram telah menentukan batas-batas perbuatan dan konten yang termasuk ke dalam pelanggaran Hak Cipta. Apabila terjadi penggunaan gambar di internet yang digunakan secara tanpa hak oleh pencipta desain filter Instagram pihak Instagram dapat menghapus konten tersebut. Selain itu, pihak Instagram juga memberikan keleluasaan tindakan kepada pengguna yang menemukan adanya pelanggaran Hak Cipta. Para pengguna dapat melaporkan konten tersebut dengan cara-cara yang dijelaskan dalam laman pusat bantuan Instagram yang dapat diakses pada https://help.instagram.com/126382350847838. Berkaitan dengan hal tersebut, Pasal 29 PP PTSE menyebutkan bahwa sudah semestinya Penyelenggara Sistem Elektronik wajib menyampaikan informasi kepada pengguna sistem elektronik. Informasi tersebut diantaranya mengenai objek yang ditransaksikan, syarat kontrak serta prosedur mencapai kesepakatan.

Banyaknya mekanisme dan pilihan tindakan hukum diharapkan dapat memperjuangkan hak-hak pencipta yang telah dilanggar oleh para pelaku. Adanya berbagai

\footnotetext{
${ }^{25}$ Abimanyu Rhesa Agatha. "Urgensi Pengawasan Layanan Konten Digital Over The Top (OTT) di Indonesia". Jurnal Kertha Negara. Vol 8 No.12 Tahun 2020. HIm, 33
} 
pilihan tindakan hukum tersebut juga merupakan bentuk pelindungan yang diberikan oleh negara kepada para pencipta khususnya pencipta yang menciptakan karyanya di internet.

\section{PENUTUP}

Berdasarkan UU Hak Cipta kasus penggunaan gambar di internet yang digunakan secara tanpa hak untuk tujuan komersil oleh pihak yang tidak bertanggung jawab merupakan suatu pelanggaran hak cipta. Hal ini didasarkan pada beberapa pengaturan dalam UU Hak Cipta yang mengatur tentang subyek pelindungan, obyek pelindungan serta pembatasan Hak Cipta. Berdasarkan analisis yang dilakukan, pencipta desain filter cerita Instagram (Instagram stories) yang menggunakan karya orang lain secara tanpa hak di dalam unsur desain filternya bukanlah pencipta yang dapat dilindungi ciptaannya karena ciptaannya merupakan hasil penjiplakan atau penggunaan karya orang lain secara tanpa hak. Gambar di internet sendiri merupakan obyek pelindungan Hak Cipta menurut Pasal 40 Ayat (1) UU Hak Cipta. Penggunaan gambar yang dikomersialisasikan oleh pihak lain secara tanpa hak termasuk ke dalam pelanggaran hak cipta. Pada kasus tersebut, pencipta desain filter cerita Instagram (Instagram filter stories) yang menggunakan karya orang lain di dalam unsur desain filternya tanpa ijin telah melanggar hak eksklusif yang dimiliki oleh pencipta gambar asli di internet, terutama hak distribusi karya berdasarkan Pasal 9 ayat (2) UU Hak Cipta.

Pihak yang dirugikan atas perbuatan komersialisasi dan penggunaan karya secara tanpa hak tersebut dapat melakukan tindakan hukum. Dalam kasus tersebut, tindakan hukum yang dapat dilakukan ialah tindakan hukum represif, baik melalui jalur pengadilan maupun jalur non pengadilan, sesuai dengan Pasal 95 dan Pasal 96 UU Hak Cipta. Di samping itu, pihak pengelola Instagram sendiri juga telah menyediakan beberapa alternatif tindakan lanjutan yang dapat diambil oleh pihak yang merasa ciptaannya digunakan oleh pihak lain secara tanpa hak dalam aplikasi Instagram.

Dalam pemanfaatan ciptaan, pengguna perlu memperhatikan etika penggunan ciptaan agar terhindar dari pelanggaran Hak Cipta. Kemudahan dalam mengakses konten yang tersebar di internet juga berisiko melanggar Hak Cipta. Oleh karena itu, UU Hak Cipta perlu dikaji kembali substansinya agar dapat mencakup pelindunganHak Cipta bagi objek-objek media digital seperti Instagram

Banyaknya alternatif tindakan hukum yang dapat dilakukan oleh pihak yang dirugikan. Pencipta harus memperhatikan mekanisme dalam setiap tindakan hukum yang dipilihnya. Pencipta juga perlu mempertimbangkan kelebihan dan kekurangan serta efektivitas tindakan yang diambilnya.

\section{DAFTAR PUSTAKA}

\section{Buku}

Saidin, OK. (2015). Aspek Hukum Hak Kekayaan Intelektual (Intellectual Property Rights)., Jakarta: Raja Grafindo Persada.

\section{Jurnal}

Agatha, Abimanyu Rhesa. (2020). Urgensi Pengawasan Layanan Konten Digital Over The Top (OTT) di Indonesia. Jurnal Kertha Negara. 8(12).

Akasih, Putri Yan Dwi. (2017), PelindunganHak Cipta di Internet Melalui Creative Commons. Business Law Review, 2.

Fanny, Rindia., Andry, Setiawan., dan Kusumaningryas, Bhakti Ivan Yudistira. (2018) Diseminasi Hukum Hak Cipta Pada Produk Digital di Kota Semarang. Jurnal Pengabdian Hukum Indonesia (Indonesian Journal of Legal Community Engagement) JPHI. 1(1). 
Girsang, Junimart. et al. (2020). Pertanggungjawaban Hukum Perusahaan Asuransi Terhadap Penolakan Klaim Atas Kehilangan Kendaraan Bermotor. Justitia: Jurnal Ilmu Hukum dan Humaniora 7(4): 819-829

Munawar, Akhmad., Effendy, Taufik. (2016). Upaya Penegakan Hukum Pelanggaran Hak Cipta Menurut Undang-Undang Nomor 28 Tahun 2014 Tentang Hak Cipta. Jurnal Al'adl. VIII(2).

Murfianti, Fitri. (2020). Hak Cipta dan Karya Seni di Era Digital. Jurnal Asintya: Jurnal Penelitian Seni Budaya. 12(1).

Paramisuari, Anak Agung Sinta., ME., Purwani Sagung Putri. (2019) PelindunganHukum Ekspresi Budaya Tradisional Dalam Bingkai Rezim Hak Cipta. Kertha Semaya: Journal Ilmu Hukum. 7.1

Permana, I Gede Ari Krisnanta., Windari, Ratna Artha., \& Mangku, Dewa Gede Sudika. (2020). Implementasi Undang-Undang Nomor. 28 tahun 2014 tentang Hak Cipta Terhadap Perlindungan Karya Cipta Program Komputer (Software) Di Pertokoan Rimo Denpasar. Jurnal Komunitas Yustisia. 1.1 55-65.

Ramli, Tasya Safira., Ramli, Ahmad M., Permata, Rika Ratna., \& Budhijanto, Danrivanto. Commercialization Of Copyright Content Through Digital Platforms In Indonesia. Progresive Law Review. Vol 1 No 1. November 2019. HIm 5

Ramli, Tasya Safiranita., Ramli, Ahmad M \& Permata, Rika Ratna. (2020). Aspek Hukum Atas Konten Hak Cipta Dikaitkan dengan Undang-Undang Nomor 19 Tahun 2016 Tentang Informasi dan Transaksi Elektronik, Jurnal Legislasi Indonesia. 17 (1).

Sopian, Pani., Mayana, Ranti Fauza., \& Safiranita, Tasya. (2021). PelindunganHak Cipta Terkait Gambar Karakter Disney yang di Transmisi Secara Ilegal melalui Media Elektronik, Jurnal Kertha Semaya, 9 (6)

Sudjana. (2016). Sistem PelindunganAtas Ciptaan Berdasarkan Undang-Undang Nomor 28 Tahun 2014 Tentang Hak Cipta dalam Perspektif Cyber law. Jurnal Ilmu Hukum Universitas Parahyangan. 2 (2).

Sudjana. (2019). Pembatasan Perlindungan Kekayaan Intelektual (Hak Cipta) dalam Perspektif Hak Asasi Manusia. Jurnal HAM. 10 (1).

Suryawan, Made Angga Adi., \& Resen, Made Gde Subha Karma. (2018). Pelaksanaan Penarikan Royalti Oleh Yayasan Karya Cipta Indonesia Wilayah Bali Pada Restoran Di Kabupaten Gianyar Atas Penggunaan Karya Cipta Lagu Dan Musik. Kertha Semaya: Journal Ilmu Hukum. 4(3)

Tobing, Abel Nicholas L.. Permata, Rika Ratna., dan Ramli, Tasya Safiranita. (2021). Tindakan Hukum atas Pelanggaran Hak Cipta pada Digitalisasi Ciptaan Melaui Media Over The Top. Jurnal Sains Sosio Humaniora, 5(1).

\section{Peraturan Perundang-Undangan}

Undang-Undang Nomor 28 Tahun 2014 tentang Hak Cipta

Undang-Undang Nomor 11 Tahun 2008 juncto Undang-undang Nomor 19 Tahun 2016 Tentang Informasi dan Transaksi Elektronik

Peraturan Pemerintah Republik Indonesia Nomor 71 Tahun 2019 tentang Penyelenggaran Sistem dan Transaksi Elektronik

\section{Website}


Fathoni. Hilman. (2018). Pengalihan Hak Cipta (Copyright Transfer Agreement) Ciptaan vs Pelisensian Ciptaan. Diambil 7 September 2021, dari https://creativecommons.or.id/2018/10/pengalihan-hak-cipta-copyrighttransfer-ciptaan-vs-pelisensian-ciptaan/ pada tanggal Pukul 22.00 